\title{
Gods and Services: Religious Groups and Sexual Orientation Discrimination
}

\author{
RUSSELL SANDBERG \\ Doctoral Student, Cardiff Law School \\ Associate, Centre for Law and Religion, Cardiff University
}

Exemptions for religious groups from generally applicable laws are by no means unusual, especially in the field of discrimination law. ${ }^{1}$ However, exemptions from laws prohibiting discrimination on grounds of sexual orientation have proved particularly controversial. The legality of exemptions in regulations prohibiting discrimination on grounds of sexual orientation in the employment sphere has been the subject of judicial review ${ }^{2}$ and the scope of those exemptions has also been judicially examined. ${ }^{3}$ The extension to prohibit discrimination on grounds of sexual orientation in the provision of goods and services $^{4}$ has proved controversial, and case law on the extent of the religious exemption included in the British regulations is awaited. ${ }^{5}$ In the meantime, a recent judicial review of the corresponding Northern Ireland regulations, ${ }^{6}$ which were enacted prior to the British regulations, may be illuminating.

\section{THE NORTHERN IRELAND REGULATIONS}

Like the British regulations, the Northern Ireland regulations outlaw direct and indirect discrimination and victimisation on grounds of sexual orientation in the provisions of goods and services. Unlike their British counterparts, the Northern Ireland regulations also outlaw harassment. Both sets of regulations have various exemptions, including an exemption for 'organisations relating to religion or belief'. ${ }^{7}$ Both provide a purposive definition of the term 'organisations relating to religion or belief' ${ }^{8}$ and state that such organisations may lawfully

1 See R Sandberg and N Doe, 'Religious exemptions in discrimination law' (2007) 66(2) Cambridge Law Journal 302-312.

$2 \quad R$ (Amicus MSF Section) v Secretary of State for Trade and Industry [2004] EWHC 860.

3 Reaney $v$ Hereford Diocesan Board Of Finance [2007] ET judgment 17 July 2007 (Case No: 1602844/ 2006).

4 Equality Act (Sexual Orientation) Regulations 2007, SI 2007/1263.

5 Concern culminated in a letter written by Cardinal Cormac Murphy-O'Connor, the head of the Roman Catholic Church in England and Wales, to the Cabinet in January 2007, focusing specifically on the need for an exemption that would allow the Catholic Adoption Agencies lawfully to refuse to place children with homosexual couples.

6 Equality Act (Sexual Orientation) Regulations (Northern Ireland) 2006, SR 2006/439.

7 Equality Act (Sexual Orientation) Regulations 2007, reg 14; Equality Act (Sexual Orientation) Regulations (Northern Ireland) 2006, reg 16.

8 Compare this with the regulations prohibiting discrimination in relation to employment, where exemptions are addressed to 'organised religions': see Sex Discrimination Act 1975, s 19, and Employment Equality (Sexual Orientation) Regulations 2003, SI 2003/1661, reg 7(3). The definition 
restrict the provision of goods and services and membership or participation in the organisation on one of two bases. The first is 'if it is necessary to comply with the doctrine of the organisation', the second is 'so as to avoid conflicting with the strongly held religious convictions of a significant number of the religion's followers'. Both regulations state that this exemption is lost if an organisation makes provision with and 'on behalf of a public authority under the terms of a contract'. 9 Given these similarities, the recent judicial review into the making of the Northern Ireland regulations may shed light upon the British situation.

\section{GROUNDS OF REVIEW}

The enactment of the Northern Ireland regulations proved controversial. ${ }^{10}$ A number of Christian organisations and charities ${ }^{11}$ sought a judicial review of the regulations on four grounds, contending that:

i. The consultation prior to the making of the regulations was insufficient;

ii. The regulations breached their rights under the European Convention on Human Rights (ECHR);

iii. The Office of the First Minister and Deputy First Minister misunderstood the nature and effect of the regulations; and

iv. The regulations were ultra vires as they represented a breach of section 24 of the Northern Ireland Act 1998.

In the Northern Ireland High Court, Weatherup J considered these grounds in turn. ${ }^{12}$

In relation to the first ground, consultation, the applicants contended that the Office of the First Minister and Deputy First Minister failed properly to consult interested parties about the content of the regulations. Weatherup J noted that, although there were no special circumstances giving rise to a public law duty to

of an 'organisation relating to religion or belief' differs from that used in religious discrimination in two respects: the fifth purpose of such an organisation ('to improve relations, to maintain good relations, between persons of different religions or beliefs') is omitted and it is also stated that the section does not apply to educational organisations: compare Equality Act 2006, s 57.

9 This explains why the Roman Catholic objection to the regulations focused specifically on the need for an exemption for Catholic Adoption Agencies.

10 In January 2007, after the regulations had come into effect, opposition peer Lord Morrow moved a debate in the House of Lords, (unsuccessfully) praying that they be annulled: House of Lords Hansard, 9 Jan 2007: Column 179.

11 Namely: the Christian Institute, the Reformed Presbyterian Church in Ireland, the Congregational Union of Ireland, the Evangelical Presbyterian Church of Ireland, the Association of Baptist Churches in Ireland, the Fellowship of Independent Methodist Churches and Christian Camping International (UK) Limited.

The Christian Institute, Re Application for Judicial Review [2007] NIQB 66. 
consult any of the applicants, the fact that there was consultation meant that the respondents were under a duty to consult properly. Although the consultation period was shorter than that usually recommended and included the main holiday season, Weatherup J noted that this duty to consult properly had not been breached: the general guidance ${ }^{13}$ had been taken into account and such guidance was not to be applied rigidly. The consultation period was adequate in the circumstances.

However, Weatherup J found that the consultation on the harassment provisions merited separate consideration. The consultation document had stated that the respondents were 'minded to accept that it is not appropriate to legislate for harassment in these Regulations' and that this should be left for the future Single Equality Bill. ${ }^{14}$ Nonetheless, despite this, harassment provisions were included in the final regulations. Although the consultation paper did invite views and reasons for the inclusion of the harassment provisions, the applicants contended that the inclusion of such provisions meant that the regulations were fundamentally different from the scheme envisaged in the consultation paper and therefore were unfair. Weatherup J agreed: 'it was unfair to the consultees who agreed with the proposed deferral of harassment to induce them not to address their objections to the respondent and then to introduce harassment provisions'. ${ }^{15}$ Moreover, the applicants contended that the harassment provisions were unlawful in any event for being too widely drawn, extending their reach beyond that of discrimination: while EU law establishing equal treatment in employment ${ }^{16}$ defined harassment as engaging in unwanted conduct which has the purpose of violating the victim's dignity and creating an intimidating, hostile, degrading or offensive environment for the victim, the regulations had replaced the conjunctive 'and' with the disjunctive 'or'. Furthermore, the regulations went beyond the Directive in stating that the test of whether conduct had this purpose was one of reasonableness, taking into account 'in particular' the perception of the victim. These concerns were shared by the Joint Committee on Human Rights, which expressed the concern that the wideness of the provision and the vague definition gave rise to a risk of incompatibility with Articles 9 and 10 of the ECHR. ${ }^{17}$ Weatherup J held that the absence of proper consultation on the harassment provisions, coupled with concern as to their extended reach meant that the harassment provisions in the regulations would be quashed.

Cabinet Office, Code of Practice on Consultation (January 2004).

In pursuance of the Labour Party's manifesto pledge; see Labour Party Manifesto 2005, Britain: forward not back, p 112.

[2007] NIQB 66 at para 34.

Council Directive 2000/78/EC (27 November 2000).

House of Lords and House of Commons Joint Committee on Human Rights, 'Legislative Scrutiny: Sexual Orientation Regulations' (sixth report of Session 2006-2007), 26 February 2007, para 57. 
Weatherup J's decision in relation to the harassment provisions coloured the remainder of his judgment. In relation to the second ground, the European Convention on Human Rights, the applicants contended that the protection afforded to sexual orientation in accordance with the right to respect for private life under Article 8 of the Convention outweighed the protection afforded to the manifestation of religious belief under Article 9. However, the respondents contended that the court should not examine the regulations in the abstract and that such challenges would be fact-specific and should be determined on a case-by-case basis as challenges were made by means of court proceedings. Weatherup J accepted the contention of the respondents but noted, somewhat ambiguously, that it would be "possible to outline the general approach that applies to consideration of alleged breaches of rights under the European Convention which might give indications as to how particular instances might be dealt with, while at the same time illustrating the fine dividing lines that may be drawn in particular cases depending on all the circumstances of a particular case'. ${ }^{18}$ Although Weatherup J considered this point in some detail, he did not accept any generalised complaints concerning the regulations. However, he did reach some particular conclusions, such as finding that the regulations do not apply to the school curriculum. With regard to Article 9, he noted that, although the right to manifest religion or belief was engaged ${ }^{19}$ and the introduction of the regulations would result in 'instances of material interference' with the right, ${ }^{20}$ this might be justified under Article 9(2): the regulations were 'prescribed by law', had the legitimate aim of the protection of the rights of others and were proportionate. This was especially so since many of the specific worries were concerned with the (now-to-be-quashed) harassment provisions. Weatherup J also commented upon the position of religious persons engaged in a commercial activity who wished not to undertake action that promoted homosexuality, such as a printer who sought to refuse to print business cards promoting homosexual publications. He noted that the exemption for 'organisations relating to religion or belief' was lost if their sole or main purpose was commercial. He suggested that a different approach, favoured in the Canadian jurisprudence, ${ }^{21}$ might be preferable, namely that believers are not entitled to undertake action that promotes that which the essence of their belief teaches to be wrong. He also commented that, where

19 Since the orthodox Christian belief that the practice of homosexuality is sinful 'is a long established part of the belief system of the world's major religions' and 'is not a belief that is unworthy of recognition' (at para 50). ing religious dress and symbols in England and Wales: see M Hill and R Sandberg, 'Is nothing sacred? Clashing symbols in a secular world' (2007) Public Law 488-506 and R Sandberg, 'Controversial recent claims to religious liberty' (2008) Law Quarterly Review (forthcoming). 
activities were outside the scope of the exemption, 'a balance of rights will be required'. ${ }^{22}$ These comments, though mere obiter, give some reflection of the myriad of issues yet to be fully resolved and point to the importance of Weatherup J's finding that questions of whether the regulations breach the ECHR are fact-specific and need to be considered judicially on a case-by-case basis.

Weatherup J dealt with the third and fourth grounds in a swifter manner. In relation to the contention that the respondents misunderstood the nature and effect of the regulations, Weatherup J observed that these points now added nothing to the debate in light of his findings regarding the harassment provision and the non-applicability of the regulations to the school curriculum. In relation to the fourth ground, the applicants contended that the regulations were ultra vires as a breach of section 24 of the Northern Ireland Act 1998, which provides that a Minister or Northern Ireland department has no power to perform any act which, inter alia, 'discriminates against a person or a class of person on the grounds of religious belief'. Weatherup J held that there was no basis for interfering with the regulations relying on section 24 , since he was satisfied that the regulations did not treat evangelical Christians less favourably than others.

\section{CONCLUSIONS}

The headline from Weatherup J's judgment is undoubtedly the decision that the harassment provisions should be set aside. Although the harassment provisions were not included in the British regulations, this part of the decision is still of importance, since Weatherup J's comments may apply to other harassment provisions found in English law. ${ }^{23}$ Perhaps equally important, though, is Weatherup J's elucidation of the plethora of unresolved issues and his assertion that these are to be resolved on a case-by-case basis. Weatherup J's treatment of Article 9 seems preferable to the approach taken in a number of recent decisions in England and Wales, and his comments regarding the situation of believers engaged in commercial activities question the harsh line currently drawn under human rights jurisprudence. ${ }^{24}$ The judgment of the Northern Ireland High Court thus stresses that the enactment of the sexual orientation regulations is the beginning rather than the end of the debate.

doi: $10.1017 /$ So956618Xo8001208

22 [2007] NIQB 66 at para 88.

23 Most notably laws prohibiting discrimination in the employment sphere, including the Employment Equality (Sex Discrimination) Regulations 2005, SI 2005/2467. It is notable that the harassment charge in Reaney $v$ Hereford Diocesan Board of Finance was unsuccessful.

24 Strasbourg institutions recognise what may be styled the 'specific situation rule': where the claimant has voluntary submitted to a voluntary system of rules, this 'specific situation' may limit the right that they would otherwise enjoy under Article 9. Recent cases in England and Wales seem to have extended the application of this rule: see note 20 above. 